\title{
Multiple Site European Union State Trial Indicator
}

National Cancer Institute

\section{Source}

National Cancer Institute. Multiple Site European Union State Trial Indicator. NCI

Thesaurus. Code C127794.

An indication as to whether the clinical study is being conducted at multiple sites within the European Union member state concerned by the application. 